symptoms continued after dilatation; 13 others had occasional symptoms only. Though health gradually deteriorates even if symptoms are controlled by dilatation and drugs, 41 patients had a satisfactory quality of life after surgery (groups $S_{A, B}$ and $C$ ).

There was no appreciable difference in either postoperative mortality or recurrence of symptoms in the two groups having conservative or radical surgery. The 30 day mortality was similar to that reported for younger patients ${ }^{35}$ and might be reduced with better selection of patients. The five year survival in our patients was $68 \%$. More elderly patients should be considered for surgery for oesophageal stricture.

1 Stoddard CJ, Simms JM. Dilatation of benign oesophageal strictures in the outpatient department. Br 7 Surg 1984;71:752-3.

2 Croker JR, Vallon AG, Cotton PB. Benign oesophageal stricture in the elderlyuse of cimetidine and fibre-optic dilatation. Age Ageing 1980;9:53-8.

3 Williamson RCN. The management of peptic oesophageal stricture. $B r f$ Sur $1975 ; 62: 448-54$

4 Fanshal S, Bush JW. A health-status index and its application to health-service outcomes. Operations Research 1970;18:1021-66.

Mohansingh MP. Mortality of oesophageal surgery in the elderly. Br f Surg 1976;63:579-80.

(Accepted 12 September 1989)

\section{Antral Helicobacter pylori, hypergastrinaemia, and duodenal ulcers: effect of eradicating tho organism}

\author{
Sassoon Levi, Kate Beardshall, Ian Swift, \\ William Foulkes, Ray Playford, Prodyot Ghosh, \\ John Calam
}

Department of Medicine,
Royal Postgraduate
Medical School, London
W12 ONN
Sassoon Levi, MRCP,
honorary registrar
Kate Beardshall, BSC,
research fellow
Ian Swift, FRCS, registrar
William Foulkes, MRCP,
registrar
Ray Playford, MRCP, registrar
Prodyot Ghosh, MRCP,
registrar
John Calam, FRCP, senior
lecturer

Correspondence to: Dr Calam.

Br Med f 1989;299:1504-5
There is strong epidemiological evidence to support a relation between colonisation of the gastric antrum with Helicobacter pylori (previously Campylobacter pylori) and duodenal ulcers,' though the basis of this association is speculative. We recently showed that in patients with duodenal ulcers secretion of gastric acid stimulated by pentagastrin and postprandial plasma gastrin concentrations are significantly higher in patients positive for $H$ pylori than in those negative for the organism..$^{2}$ In the present study we examined whether the high postprandial gastrin concentrations respond to treatment that eradicates $H$ pylori.

\section{Patients, methods, and results}

We studied 51 patients with active duodenal ulcers. Seven were negative for $H$ pylori and 44 positive on urease testing of antral biopsy specimens. ${ }^{2}$ Secretion of gastric acid was determined with pentagastrin $(6 \mu \mathrm{g} / \mathrm{kg} / \mathrm{h})$. Venous blood was collected before and after a standard meal for radioimmunoassay of gastrin.

Peak secretion of acid stimulated by pentagastrin was $45 \cdot 2$ (SEM 3.0$) \mathrm{mmol} / \mathrm{h}$ in the patients who were positive for $H$ pylori compared with $29 \cdot 7(4 \cdot 0) \mathrm{mmol} / \mathrm{h}$ in those who were negative $(p<0.05)$. Basal gastrin concentrations were significantly higher in the patients who were positive for $H$ pylori $(13 \cdot 1(2 \cdot 0)$ $v 6.3(2.6) \mathrm{pmol} / \mathrm{l}, \mathrm{p}<0.05)$. Integrated plasma gastrin responses to the standard meal were 1564 (267) pmol.min/l in the patients positive for $H$ pylori and 965 (248) pmol.min/l in those negative for $H$ pylor $(\mathrm{p}<0.05)$.

Ten of the patients positive for $H$ pylori were treated with metronidazole $400 \mathrm{mg}$ thrice daily for two weeks and colloidal bismuth subcitrate $120 \mathrm{mg}$ four times daily for four weeks. ${ }^{3}$ Two days after completing treatment nine patients were negative for the organism. Integrated postprandial gastrin responses fell from 1184 (350) to 498 (117) pmol.min/l $(\mathrm{p}=0.005)$ while peak rates of secretion of acid remained unchanged (figure). Basal gastrin concentrations, however, were not significantly lower after treatment $(7 \cdot 5(1.8) v 6.7$ (1.9) $\mathrm{pmol} / \mathrm{l}$, respectively).

\section{Comment}

We showed that eradicating antral $H$ pylori in patients with duodenal ulcers leads to a significant drop in the postprandial response of plasma gastrin concentration. This supports our contention that $H$ pylori is responsible for hypergastrinaemia in patients with duodenal ulcers. ${ }^{2}$

Patients with duodenal ulcer disease tend to have higher rates of secretion of gastric acid and higher postprandial plasma gastrin concentrations than controls. Walsh et al showed that a low intragastric $\mathrm{pH}$ inhibits release of gastrin less effectively in patients with duodenal ulcer disease than in normal subjects. ${ }^{4}$ On the basis of our recent results ${ }^{2}$ we proposed that $H$ pylori in the gastric antrum increases the release of gastrin. $H$ pylori produces a powerful urease that splits
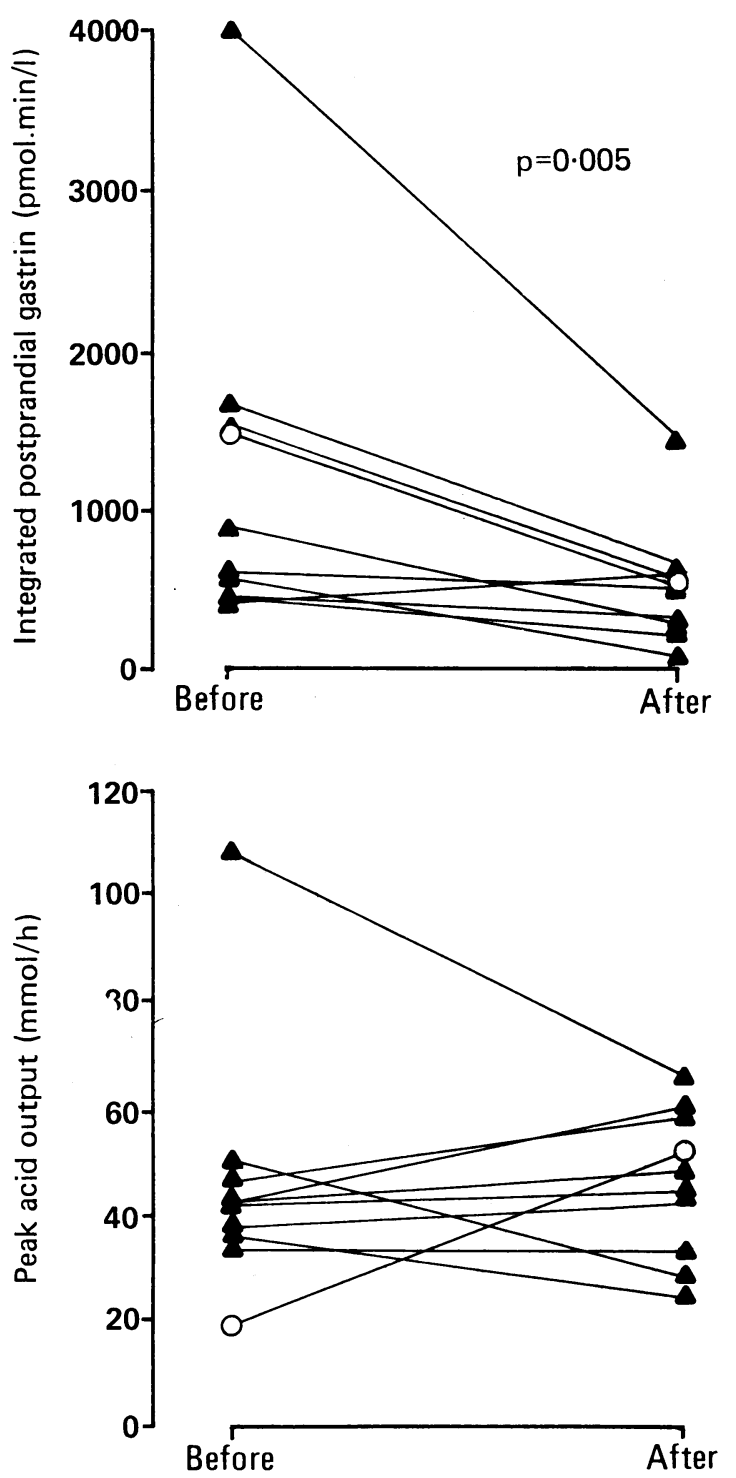

Changes in integrated postprandial gastrin responses and peak acid output in 10 patients before and after treatment with colloidal bismuth subcitrate for four weeks and metronidazole for two weeks. $\mathrm{O}-\mathrm{O}=$ Patient in whom urease test after treatment yielded weakly positive result 
urea in the stomach to produce ammonia. We therefore postulate that ammonia increases the $\mathrm{pH}$ in the mucus layer that overlies the gastric antrum, resulting in impairment of the normal inhibition of gastrin release by intraluminal acid.

This is the first report of a fall in postprandial plasma gastrin responses after eradication of $H$ pylori in patients with duodenal ulcers. This could explain the reduced likelihood of relapse of ulcers in patients treated with agents that suppress or eradicate $H$ pylori. The fall in postprandial plasma gastrin concentrations, which does not occur after treatment with $\mathrm{H}_{2}$ antagonists $^{5}$ and is therefore not simply a result of the ulcer healing, would be expected to result in a diminished postprandial secretory drive on the gastric parietal cells. Another probable long term result of the lower gastrin concentrations is a reduction in the number of parietal cells owing to a reduction in the trophic effect of gastrin on these cells. Peak acid output, which reflects the parietal cell mass, did not fall significantly in our patients after one month of treatment to eradicate $H$ pylori despite the lower gastrin concentrations. Thus a longer period of treatment may be needed before the number of parietal cells falls.

We thank Sister M L Francis Reme and her endoscopy staff for their hard work and $\mathrm{Mr}$ John Spencer for allowing us to study his patients. SL was supported by the British Digestive Foundation, KB by the Wellcome Trust, and RP by the Medical Research Council.

1 Marshall BJ, Goodwin CS, Warren JR, et al. Prospective double-blind trial of duodenal ulcer relapse after eradication of Campylobacter pylori. Lance 1988;ii:1467-9.

2 Levi S, Beardshall K, Haddad G, Playford R, Ghosh P, Calam J. Campylobacter pylori and duodenal ulcers: the gastrin link. Lancet 1989;i:1167-8.

3 O'Riordan T, 'Tobin A, Beattie S, Sweeney E, Keane C, O'Morain C. Adjuvant metronidazole improves eradication of Campylobacter pylori in duodenal metronidazole improves eradication of Campylobacter pylor1 in

4 Walsh JH, Richardson CT, Fordtran JS. pH Dependence of acid secretion and alsh JH, Richardson CT, Fordtran JS. pH Dependence of acid secretion
gastrin release in normal and ulcer subjects. $\mathcal{f}$ Clin Invest $1975 ; 55: 462-8$. gastrin release in normal and ulcer subjects. F Clin Invest 1975;55:462-8.
5 Forrest JAH, Fettes MR, McLaughlin GP, Heading RC. Effect of long-term cimetidine on gastric secretion, serum gastrin, and gastric emptying. Gut 1979;20:404-7.

(Accepted 20 September 1989)

\section{Erythrocyte zinc concentrations in subacute (de Quervain's) thyroiditis}

\section{C Chow, C C Shek, Y T Mak, C S Cockram, R Swaminathan}

Departments of Medicine and Chemical Pathology, Chinese University of Hong Kong, Shatin, NT, Hong Kong

C C Chow, MRCP, medical officer, department of medicine $\mathrm{CC}$ Shek, MB, medical officer, department of chemical pathology

Y T Mak, MPHIL, scientific officer, department of chemical pathology

C S Cockram, FRCP, senior

lecturer in medicine

R Swaminathan, MRCPATH,

professor of chemical pathology

Correspondence to:

Dr Shek.

BrMed F 1989;299:1505-6
Patients with subacute thyroiditis classically present with fever, neck pain, and a tender goitre. Functional changes in thyroid state include both hyperthyroidism and hypothyroidism. Constitutional symptoms may, however, be absent and patients may present with features of hyperthyroidism alone, thus making differentiation from other causes of hyperthyroidism difficult. Nevertheless, differentiation is important as the implications for treatment are different. In such cases measurement of the uptake of radioiodine by the thyroid gland is useful, but it may not be measured unless thyroiditis is suspected. Thus the disorder may be misdiagnosed and patients given inappropriate treatment.

As patients with subacute thyroiditis are hyperthyroid for a short time a marker that reflects the duration of their hyperthyroidism might be useful in differentiating their condition from established hyperthyroidism - for example, that due to Graves' disease. Erythrocyte zinc concentrations are decreased in patients with established hyperthyroidism. 'Because, however, the circulating life span' of erythrocytes is long, the erythrocyte zinc concentration reflects the integrated functional state of the thyroid over a period of months. Thus the erythrocyte zinc concentration may be used to differentiate between transient hyperthyroidism and established hyperthyroidism lasting more than two to three months. We previously reported that the erythrocyte zinc concentration differentiated between transient hyperthyroxinaemia associated with hyperemesis gravidarum and preexisting thyrotoxicosis, ${ }^{2}$ and we report the results in patients with transient hyperthyroidism associated with subacute thyroiditis.

\section{Patients, methods, and results}

We studied five patients (four women and one man ranging in age from 35 to 42 ) with clinically incontrovertible subacute thyroiditis. Hyperthyroidism was suspected clinically in four of them and was confirmed in all five by measuring the concentrations of thyroid hormones. All five patients presented with fever, anterior neck pain, a tender goitre, and a raised erythrocyte sedimentation rate (mean $111 \mathrm{~mm}$ in the first hour, range 58-150); the uptake of radioactive iodine by the thyroid gland was subnormal in all five and none had thyroid antibodies.

Erythrocyte zinc concentrations were measured by atomic absorption spectrophotometry. ${ }^{\prime}$ The coefficient of variation between days was $5 \%$.

Erythrocyte zinc concentrations in the five patients were compared with those in 30 patients with established thyrotoxicosis and 110 control patients who were euthyroid (figure). The mean erythrocyte zinc

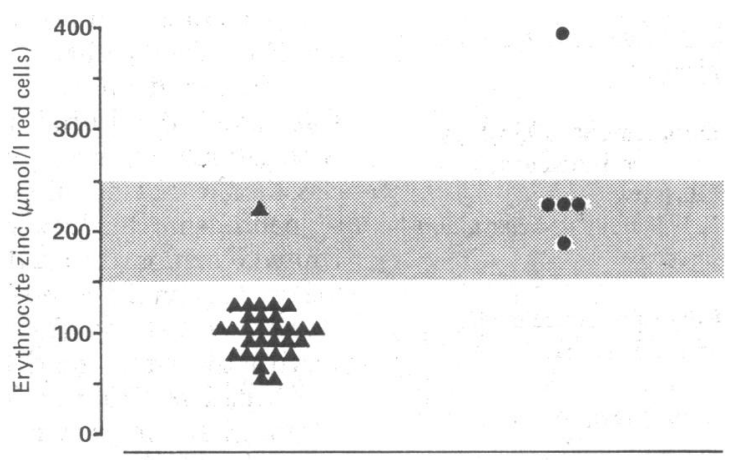

Hyperthyroidism

Subacute thyroiditis

Erythrocyte zinc concentrations in 30 patients with established thyrotoxicosis $(\boldsymbol{\Delta})$ and five patients with subacute thyroiditis $(\bullet)$. Hatched area shows 2 SDs of mean in 110 euthyroid control patients

concentration in the patients with thyrotoxicosis (105 (SD 64) $\mu \mathrm{mol} / \mathrm{l}$ red cells) was significantly lower than that in the euthyroid control patients (196 (50) $\mu \mathrm{mol} / 1$ red cells, $p<0 \cdot 001)$. The mean erythrocyte zinc concentration in the patients with subacute thyroiditis was, however, $255 \mu \mathrm{mol} / \mathrm{l}$ red cells (range 185.6-394.7) and not significantly different from that in the control group. One patient had an erythrocyte zinc concentration of $394.7 \mu \mathrm{mol} / 1$ red cells but he also had a thalassaemia trait with microcytosis.

\section{Comment}

The normal erythrocyte zinc concentrations in our patients show that their hyperthyroidism was transient and therefore provides additional evidence to support 